DOI: $10.15193 /$ zntj/2020/122/326

\title{
ROBERT GAJDA, DANUTA KOŁOŻYN-KRAJEWSKA
EKONOMICZNY ASPEKT BEZPIECZEŃSTWA ŻYWNOŚCIOWEGO W GOSPODARSTWACH DOMOWYCH OSÓB STARSZYCH Z UWZGLĘDNIENIEM WYBRANYCH CECH SOCJODEMOGRAFICZNYCH

\begin{abstract}
Streszczenie
Podstawowe przyczyny braku bezpieczeństwa żywnościowego w gospodarstwach domowych osób starszych związane są z ubóstwem, polityką społeczną i dochodami. Celem pracy była ocena w aspekcie ekonomicznym bezpieczeństwa żywnościowego w gospodarstwach domowych osób starszych z uwzględnieniem wybranych cech socjodemograficznych. W badaniach zastosowano autorski kwestionariusz ankiety. Ponad $25 \%$ badanych wyraziło opinię, że w ich gospodarstwach domowych brakowało żywności lub występowały obawy związane z jej brakiem z powodu ograniczonych środków finansowych. Płeć i wiek nie były czynnikami statystycznie istotnie różnicującymi taką opinię (zgodnie $z$ testem $\chi^{2}$ ), ale w ramach analizy MCA (Multiple Correspondence Analysis) wykazano związek między tą opinią a wiekiem badanych (75 lat i więcej). Z kolei miejsce zamieszkania, wykształcenie i skład osobowy gospodarstwa domowego respondentów to cechy socjodemograficzne, które statystycznie istotnie różnicowały powyższą opinię badanych (test $\chi^{2}$ ). Ponadto na podstawie analizy MCA wykazano związek między: zamieszkaniem na wsi, wykształceniem podstawowym oraz zamieszkaniem bez partnera, ale $\mathrm{z}$ rodziną a opinią o braku bezpieczeństwa żywnościowego. Zapewnienie bezpieczeństwa żywnościowego w gospodarstwach domowych osób starszych wymaga opracowania strategii pomocy państwowej i społecznej.
\end{abstract}

Słowa kluczowe: bezpieczeństwo żywnościowe, osoby starsze, badania ankietowe, cechy socjodemograficzne

\section{Wprowadzenie}

Jednym z praw przysługujących konsumentowi jest prawo do zaspokojenia podstawowych potrzeb, do których zalicza się potrzeby żywieniowe. Zagwarantowanie prawa do tego rodzaju potrzeb wymaga bezpieczeństwa żywnościowego [2]. Obecnie

Dr inż. R. Gajda, Katedra Żywienia Człowieka, Wydz. Biotechnologii i Nauk o Żywności, Uniwersytet Przyrodniczy we Wroctawiu, ul. Norwida 25, 50-375 Wroctaw, prof. dr hab. D. Kolożyn-Krajewska, Katedra Dietetyki i Badań Żywności, Wydz. Nauk Ścislych, Przyrodniczych i Technicznych, Uniwersytet Humanistyczno-Przyrodniczy im. J. Dlugosza w Częstochowie, ul. Armii Krajowej 13/15, 42-200 Częstochowa.Kontakt: robert.gajda@upwr.edu.pl 
w literaturze funkcjonuje wiele definicji bezpieczeństwa żywnościowego [15, 22], jednak najczęściej cytowana jest definicja FAO [15], według której „bezpieczeństwo żywnościowe zachodzi wówczas, gdy wszyscy ludzie, w dowolnym czasie mają fizyczny i ekonomiczny dostęp do żywności, która jest bezpieczna pod względem zdrowotnym i zawiera optymalną ilość składników odżywczych, ponadto zaspokaja potrzeby pokarmowe i preferencje pozwalające na aktywny i zdrowy styl życia”. Zgodnie z tą definicją bezpieczeństwo żywnościowe jest zapewnione wówczas, gdy są spełnione co najmniej trzy warunki jednocześnie [17]:

- jakość produktu żywnościowego, tj. dostęp do bezpiecznej żywności oraz zawierającej niezbędny poziom energii i właściwe proporcje składników odżywczych;

- fizyczna dostępność żywności, czyli zagwarantowanie minimalnego zapotrzebowania fizjologicznego na żywność przez gospodarkę krajową;

- ekonomiczna dostępność dla gospodarstw domowych - ten rodzaj bezpieczeństwa żywnościowego jest zapewniony wówczas, gdy konsument dysponuje siłą nabywczą, która pozwala mu na zakup niezbędnych towarów i usług żywieniowych lub będzie miał dostęp do niezbędnej żywności dzięki różnym formom pomocy żywnościowej.

Uwzględniając różne definicje i koncepcje, bezpieczeństwo żywnościowe można ująć co najmniej w trzech płaszczyznach, tj. globalnej, narodowej i gospodarstwa domowego (a w nim każdego członka tego gospodarstwa) i jest determinowane przez różne warunki (wymiary) tego bezpieczeństwa, tj. dostępność fizyczną żywności, dostępność ekonomiczną żywności, społeczny dostęp do żywności czy bezpieczeństwo żywności $[9,15,18]$.

Jedną z podstaw prawidłowego funkcjonowania społeczeństwa jest zapewnienie mu bezpieczeństwa żywnościowego we wszystkich jego wymiarach, w tym zwłaszcza w wymiarze ekonomicznym [15]. Niezbędnym kryterium ekonomicznej dostępności żywności jest siła nabywcza konsumentów. Tę siłę nabywczą konsumenta na rynku żywności wyznaczają: jego dochód, ceny żywności oraz ceny pozostałych dóbr i usług [17]. Biorąc pod uwagę ekonomiczną dostępność, należy odnieść się do jednego z najbardziej adekwatnych mierników spożycia żywności - udziału wydatków na żywność w wydatkach ogółem, który przesądza również o możliwościach realizacji innych potrzeb [2]. Z raportu GUS z 2017 roku [13] wynika, że w gospodarstwach domowych emerytów i rencistów udział wydatków na żywność i napoje w ogólnych wydatkach był wyższy niż w gospodarstwach domowych w Polsce w 2016 roku i wynosił odpowiednio: 26,7 i $24,2 \%$. Na podstawie wielu badań dowiedziono, że w gospodarstwach domowych osób starszych, z różnych przyczyn i w różnym stopniu, występuje zagrożenie brakiem bezpieczeństwa żywnościowego [10, 12, 16, 23, 24, 27]. Podstawowe powody braku bezpieczeństwa żywnościowego w gospodarstwach domowych osób starszych związane są z ubóstwem, polityką społeczną i dochodami. Wykazano, że 
publiczne i prywatne emerytury ograniczają bezpieczeństwo żywnościowe w wieku starszym [16].

Celem pracy była ocena $\mathrm{w}$ aspekcie ekonomicznym bezpieczeństwa żywnościowego w gospodarstwach domowych osób starszych z uwzględnieniem wybranych cech socjodemograficznych.

\section{Material i metody badań}

Badania zostały zrealizowane w okresie od października 2018 r. do marca 2019 r. wśród osób starszych w wieku 65 lat i więcej. Grupę populacyjną stanowiło 762 seniorów, w tym 445 z województwa świętokrzyskiego i 317 z województwa śląskiego. Szczegółową charakterystykę badanej grupy pod względem socjodemograficznym przedstawiono w tab. 1.

Tabela 1. Charakterystyka socjodemograficzna badanej grupy populacyjnej osób starszych [\%] Table 1. Socio-demographic profile of the surveyed population group of the elderly people [\%]

\begin{tabular}{|c|c|c|c|}
\hline \multirow{2}{*}{$\begin{array}{l}\text { Cechy populacji } \\
\text { Population features }\end{array}$} & \multirow{2}{*}{$\begin{array}{l}\text { Ogółem } \\
\text { Total }\end{array}$} & \multicolumn{2}{|c|}{$\begin{array}{l}\text { Województwo zamieszkania } \\
\text { Province of residence }\end{array}$} \\
\hline & & $\begin{array}{l}\text { świętokrzyskie } \\
\text { Holy Cross }\end{array}$ & $\begin{array}{l}\text { śląskie } \\
\text { Silesian }\end{array}$ \\
\hline $\mathrm{N}$ & 762 & 445 & 317 \\
\hline $\begin{array}{l}\text { Płeć / Gender } \\
\text { Kobieta / Woman } \\
\text { Mężczyzna / Man }\end{array}$ & $\begin{array}{l}69,3 \\
30,7\end{array}$ & $\begin{array}{l}70,3 \\
29,7\end{array}$ & $\begin{array}{l}67,8 \\
32,2\end{array}$ \\
\hline $\begin{array}{l}\text { Wiek / Age } \\
65 \text { - } 74 \text { lata / years old } \\
75 \text { lat i więcej / years and older }\end{array}$ & $\begin{array}{l}69,8 \\
30,2\end{array}$ & $\begin{array}{l}69,0 \\
31,0\end{array}$ & $\begin{array}{l}71,0 \\
29,0\end{array}$ \\
\hline $\begin{array}{l}\text { Miejsce zamieszkania / Place of residence } \\
\text { Wieś / Village } \\
\text { Miasto / City } \leq 100000 \text { mieszkańców / inhabitants } \\
\text { Miasto / City > } 100000 \text { mieszkańców / inhabitants }\end{array}$ & $\begin{array}{l}32,1 \\
16,1 \\
51,8\end{array}$ & $\begin{array}{c}41,3 \\
20,0 \\
37,7 *\end{array}$ & $\begin{array}{c}19,2 \\
9,5 \\
71,3\end{array}$ \\
\hline $\begin{array}{l}\text { Wykształcenie / Education } \\
\text { Podstawowe / Primary } \\
\text { Zasadnicze zawodowe / Vocational } \\
\text { Średnie / Secondary } \\
\text { Wyższe / Higher }\end{array}$ & $\begin{array}{l}15,2 \\
25,8 \\
34,4 \\
24,6\end{array}$ & $\begin{array}{c}19,1 \\
26,0 \\
29,7 * \\
25,2 *\end{array}$ & $\begin{array}{l}9,8 \\
25,5 \\
41,0 \\
23,7\end{array}$ \\
\hline $\begin{array}{l}\text { Skład osobowy gospodarstwa domowego } \\
\text { Structure of people living in household } \\
\text { Mieszkam sam / I live alone } \\
\text { Mieszkam z partnerem / I live with a partner } \\
\text { Mieszkam z partnerem i z rodziną } \\
\text { I live with my partner and my family } \\
\text { Mieszkam z rodziną bez partnera } \\
\text { I live with my family, without a partner }\end{array}$ & $\begin{array}{l}31,1 \\
39,4 \\
17,8 \\
11,7\end{array}$ & $\begin{array}{l}27,6 \\
37,8 \\
20,4 * \\
14,2 *\end{array}$ & $\begin{array}{l}36,0 \\
41,6 \\
14,2 \\
8,2\end{array}$ \\
\hline
\end{tabular}

Objaśnienia / Explanatory notes:

$(*)$ - różnice statystycznie istotne między kategoriami cech populacji a województwem zamieszkania (test $\left.\chi^{2}, p \leq 0,005\right)$ / Statistically significant differences between categories of population features and voivoship of residence (test $\chi^{2}, \mathrm{p} \leq 0.005$ ). 
Badania przeprowadzono z użyciem autorskiego kwestionariusza ankiety. Dobór badanej próby został dokonany metodą kuli śnieżnej. Jest to metoda nielosowego doboru próby polegająca na rekrutowaniu respondentów przez innych ankietowanych. Rozdano 1150 kwestionariuszy ankiety wśród wszystkich osób, które wyraziły zgodę na badanie w dziewięciu Klubach Seniora w Kielcach, w dwóch klubach seniora w Częstochowie, w Stowarzyszeniu Emerytów i Rencistów w Częstochowie, w jednym Klubie Seniora w Sandomierzu oraz w czterech Kołach Gospodyń Wiejskich, $\mathrm{w}$ tym $\mathrm{w}$ trzech w powiecie kieleckim i w jednym - w powiecie częstochowskim. Jednocześnie poproszono wszystkich ankietowanych o przeprowadzenie badania (rozdanie i zebranie ankiet) wśród wszystkich chętnych z ich rodzin i środowiska zamieszkania, którzy spełniali kryterium wiekowe. W efekcie przeprowadzonych badań zebrano 798 ankiet. Po weryfikacji poprawności wypełnionych kwestionariuszy do badań zakwalifikowano 762 ankiety. Kryterium włączenia do badań był wiek respondentów 65 lat i więcej oraz reprezentowanie przez każdego uczestnika jednego gospodarstwa domowego, czyli 762 gospodarstwa domowe osób starszych zakwalifikowano do badań.

Ankieta zawierała pytania dotyczące możliwości realizacji potrzeb żywieniowych w czasie miesiąca poprzedzającego badania w aspekcie finansowym (ekonomicznym). Odpowiedzi do pytań przedstawiono na skalach nominalnych (dychotomicznych) „tak/nie”. W celu określenia uwarunkowań realizacji potrzeb żywieniowych zapytano o wybrane cechy socjodemograficzne badanych, tj. o płeć, wiek, miejsce zamieszkania, wykształcenie oraz skład osobowy gospodarstwa domowego.

Do opisu struktury populacji w ramach analizy statystycznej posłużono się liczebnościami i odsetkami osób charakteryzujących się daną cechą. Do porównania jakościowych kategorii zmiennych na skalach nominalnych oraz wyznaczenia różnic statystycznie istotnych między tymi kategoriami zastosowano test $\chi^{2}$.

Do identyfikacji struktury powiązań miedzy zmiennymi jakościowymi zastosowano wielowymiarową analizę korespondencji - MCA (Multiple Correspondence Analysis). W celu jednoczesnej analizy wielu zmiennych nominalnych, tj. opisujących możliwość realizacji potrzeb żywieniowych oraz zmiennych - wybranych cech socjodemograficznych badanej grupy populacyjnej, zastosowano macierz Burta [26]. Za kryterium wyboru liczby wymiarów przestrzeni rzutowania kategorii zmiennych przyjęto skumulowany procent bezwładności oraz kryterium osypiska [26]. Do przedstawienia graficznej kategorii zmiennych zastosowano rzut dwuwymiarowy. W celu interpretacji otrzymanych wyników dokonano oceny położenia punktów obrazujących zmienne - cechy socjodemograficzne względem wartości, tj. zmiennych opisujących możliwość realizacji potrzeb żywieniowych. 


\section{Wyniki i dyskusja}

Większość badań na temat wpływu różnych czynników na bezpieczeństwo żywnościowe $\mathrm{w}$ gospodarstwach domowych lub w obrębie jednostki przeprowadzono w Stanach Zjednoczonych i w Kanadzie, a w mniejszym stopniu we Francji i w Australii [3]. Niektóre z tych badań dotyczyły populacji charakteryzujących się niskimi dochodami [3]. Wpływ takich czynników ekonomicznych, jak dochód lub zasoby środków finansowych na poziom bezpieczeństwa żywnościowego w gospodarstwach domowych wykazano w wielu badaniach [10, 12, 16, 20, 27]. Tarasuk i wsp. [27] wykazali, że niepewny lub nieodpowiedni dostęp do żywności w gospodarstwach domowych ze względu na ograniczone środki finansowe w różnych krajach rozwiniętych jest coraz większy.

W badaniach własnych ponad $25 \%$ respondentów zaznaczyło, że w ich gospodarstwach domowych w ciągu ostatniego miesiąca przed badaniami brakowało żywności lub występowały obawy związane z jej brakiem z powodu ograniczonych środków finansowych (tab. 2). Przy zastosowaniu różnych metod oceny braku bezpieczeństwa żywnościowego w gospodarstwach domowych, w tym w gospodarstwach domowych osób starszych, wykazano brak tego bezpieczeństwa w badaniach innych autorów [10, $12,27]$. Kanada jest dobrym przykładem państwa, w którym występuje stosunkowo niskie ryzyko braku bezpieczeństwa żywności w gospodarstwach domowych osób starszych. Jak podają McIntyre i wsp. [19], publiczne emerytury zostały zapewnione Kanadyjczykom w wieku 65 lat w taki sposób, aby chronić ich przed ryzykiem braku bezpieczeństwa żywnościowego. Leroux i wsp. [16] opublikowali w 2018 roku dane, według których tylko 2,4 \% Kanadyjczyków w starszym wieku jest umiarkowanie lub poważnie zagrożonych brakiem bezpieczeństwa żywnościowego.

Darmon i Caillavet [3] oraz Leroux i wsp. [16] stwierdzili, że płeć i wiek to czynniki socjodemograficzne, które nie różnicują osób starszych pod względem bezpieczeństwa żywnościowego $[3,16]$. W badaniach własnych również nie dowiedziono statystycznie istotnego zróżnicowania (test $\chi^{2}$ ) opinii ze względu na płeć i wiek na temat braku żywności lub obaw związanych z jej brakiem z powodu ograniczonych środków finansowych w gospodarstwach domowych osób starszych (tab. 2). Na postawie wielowymiarowej analizy korespondencji (MCA) wykazano jednak związek między taką opinią a wiekiem 75 lat i więcej oraz związek między brakiem takiej opinii a wiekiem 65 - 74 lata i płcią żeńską (rys. 1).

Czynniki socjodemograficzne mające wpływ na poziom bezpieczeństwa żywnościowego w gospodarstwach domowych, takie jak miejsce zamieszkania, wykształcenie czy struktura gospodarstwa domowego wykazali Gregório i wsp. [10], Haro-Mota i wsp. [12] oraz Tarasuk i wsp. [27]. Również w badaniach własnych wykazano 
Tabela 2. Opinie na temat bezpieczeństwa żywnościowego w gospodarstwach domowych osób starszych z uwzględnieniem wybranych cech socjodemograficznych [\% odpowiedzi]

Table 2. Opinion on food security in households of the elderly people including selected sociodemographic features [\% of answers]

\begin{tabular}{|c|c|c|c|}
\hline \multirow{2}{*}{$\begin{array}{l}\text { Cechy socjodemograficzne } \\
\text { Population features }\end{array}$} & \multirow{2}{*}{$\begin{array}{l}\text { Ogółem } \\
\text { Toral }\end{array}$} & \multicolumn{2}{|c|}{$\begin{array}{c}\text { Ocena w skali dychotomicznej } \\
\text { Dichotomous score }\end{array}$} \\
\hline & & $\begin{array}{c}\text { BŻ-1 } \\
\text { tak / yes }\end{array}$ & $\begin{array}{c}\mathrm{BŻ}-1 \\
\text { nie / no }\end{array}$ \\
\hline $\mathrm{N}$ & 762 & 219 & 543 \\
\hline Ogółem / Total & 100 & 28,7 & 71,3 \\
\hline $\begin{array}{l}\text { Płeć / Gender } \\
\text { Kobieta / Woman } \\
\text { Mężczyzna / Man }\end{array}$ & $\begin{array}{l}69,3 \\
30,7\end{array}$ & $\begin{array}{l}27,8 \\
30,8\end{array}$ & $\begin{array}{l}72,2 \\
69,2\end{array}$ \\
\hline $\begin{array}{l}\text { Wiek / Age } \\
65 \text { - } 74 \text { lata / years old } \\
75 \text { lat i więcej / years and older } \\
\end{array}$ & $\begin{array}{l}69,8 \\
30,2 \\
\end{array}$ & $\begin{array}{l}26,9 \\
33,0\end{array}$ & $\begin{array}{l}73,1 \\
67,0 \\
\end{array}$ \\
\hline $\begin{array}{l}\text { Miejsce zamieszkania / Place of residence } \\
\text { Wieś / Village } \\
\text { Miasto / City } \leq 100000 \text { mieszkańców / inhabitants } \\
\text { Miasto / City }>100000 \text { mieszkańców / inhabitants }\end{array}$ & $\begin{array}{l}32,1 \\
16,1 \\
51,8\end{array}$ & $\begin{array}{l}38,4^{\mathbf{I S}} \\
26,8 \\
23,4^{*}\end{array}$ & $\begin{array}{l}61,6 \\
73,2 \\
76,6\end{array}$ \\
\hline $\begin{array}{l}\text { Wykształcenie / Education } \\
\text { Podstawowe / Primary } \\
\text { Zasadnicze zawodowe / Vocational } \\
\text { Średnie / Secondary } \\
\text { Wyższe / Higher } \\
\end{array}$ & $\begin{array}{l}15,2 \\
25,8 \\
34,4 \\
24,6\end{array}$ & $\begin{array}{c}53,5^{\mathbf{I S}} \\
33,0 \\
26,7^{*} \\
11,8^{*}\end{array}$ & $\begin{array}{l}46,5 \\
67,0 \\
73,3 \\
88,2\end{array}$ \\
\hline $\begin{array}{l}\text { Skład osobowy gospodarstwa domowego } \\
\text { Structure of people living in household } \\
\text { Mieszkam sam / I live alone } \\
\text { Mieszkam z partnerem / I live with a partner } \\
\text { Mieszkam z partnerem i z rodziną } \\
\text { I live with my partner and my family } \\
\text { Mieszkam z rodziną bez partnera } \\
\text { I live with my family, without a partner }\end{array}$ & $\begin{array}{l}31,1 \\
39,4 \\
17,8 \\
11,7\end{array}$ & $\begin{array}{l}36,7^{\mathbf{I S}} \\
21,3 \\
25,7^{*} \\
37,1^{*}\end{array}$ & $\begin{array}{l}63,3 \\
78,7 \\
74,3 \\
62,9\end{array}$ \\
\hline
\end{tabular}

Objaśnienia / Explanatory notes:

BŻ-1 tak - brak żywności lub obawy związane z jej brakiem (w ciągu miesiąca poprzedzającego badania) z powodu ograniczonych środków finansowych / BŻ-1 yes - food shortage or concern about food shortage (during the month prior to survey) due to limited financial means; BŻ-1 nie - nie wskazano braku żywności lub obaw związanych z jej brakiem (w ciągu miesiąca poprzedzającego badania) z powodu ograniczonych środków finansowych / BŻ-1 no - neither food shortage nor concerns about food shortage were pointed out (during the month prior to survey); $(*)$ - różnice statystycznie istotne między kategoriami cech socjodemograficznych badanych dla odpowiedzi „brak żywności lub obawy związane z jej brakiem (co najmniej raz w miesiącu) z powodu braku środków finansowych" (test $\chi^{2}, p \leq 0,005$ ) / statistically significant differences between the categories of socio-demographic features surveyed as regards the response „food shortage or concern about food (at least once a month) due to lack of financial means" (test $\chi^{2}$, $\mathrm{p} \leq 0.005)$. 


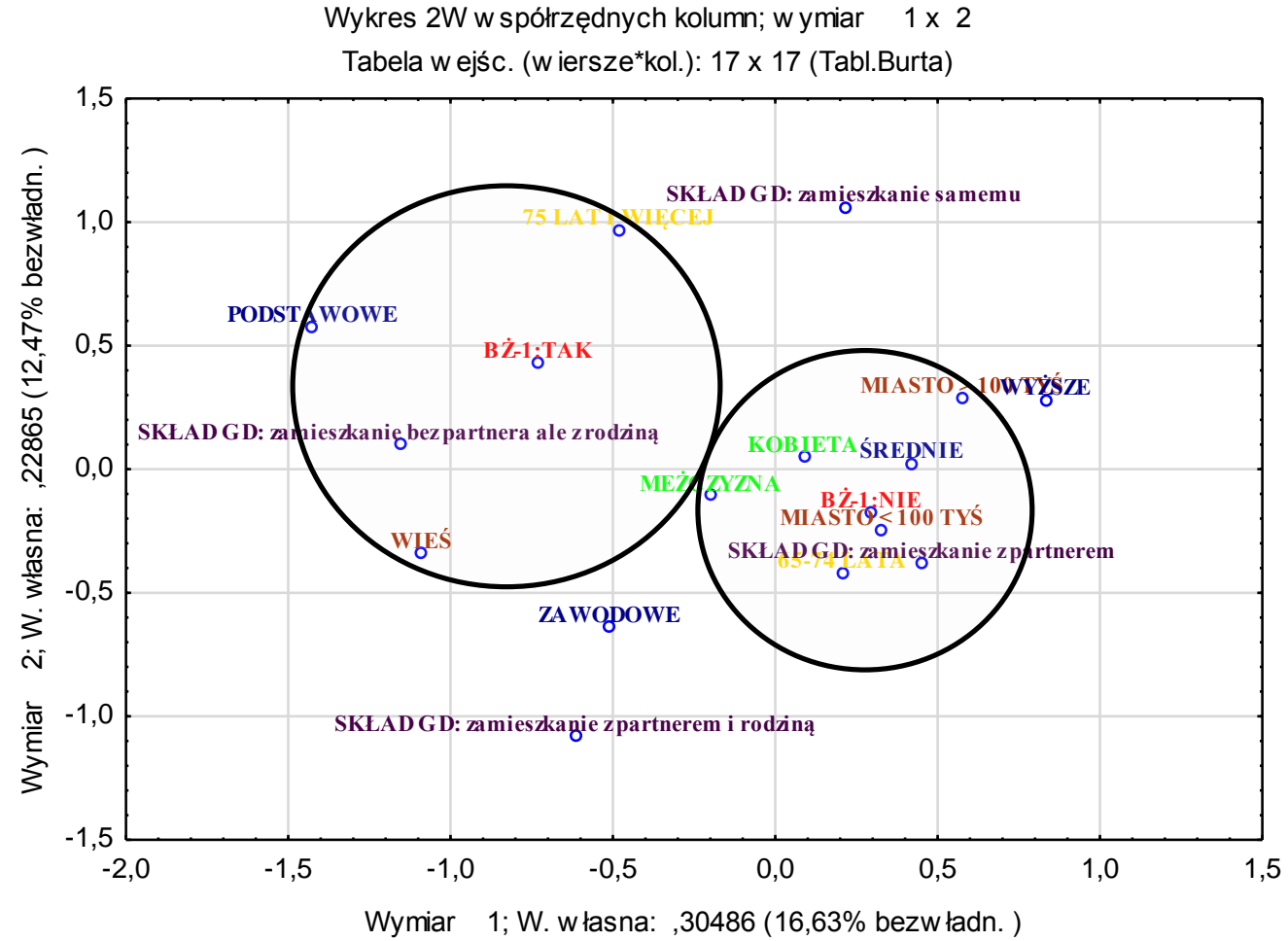

Objaśnienia czynników socjodemograficznych jak w tab. 1. / Explanations of socio-demographic features as in Tab. 1.

Rys. 1. Struktura związku między czynnikiem opisującym możliwość zapewnienia bezpieczeństwa żywnościowego w gospodarstwach domowych osób starszych (BŻ-1 tak; BŻ-1 nie) a ich wybranymi cechami socjodemograficznymi

Fig. 1. Structure of correlation between factor describing the possibility of ensuring food safety in households of the elderly people (BŻ-1 yes; BŻ-1 no) and their selected socio-demographic features

zarówno statystycznie istotne zróżnicowanie odsetka opinii (test $\chi^{2}$ ) na temat braku bezpieczeństwa żywnościowego w gospodarstwach osób starszych z powodu ograniczonych środków finansowych, po uwzględnieniu miejsca zamieszkania, wykształcenia i składu osobowego gospodarstwa domowego tych osób (tab. 2). Wykazano także związek (MCA) między taką opinią a zamieszkaniem na wsi, wykształceniem podstawowym, zamieszkaniem bez partnera, ale $\mathrm{z}$ rodziną (rys. 1 ). $\mathrm{Z}$ analizy tych zależności (tab. 2) wynika, że statystycznie istotnie częściej brak żywności lub obawy związane z jej brakiem z powodów ograniczonych środków finansowych dotyczyły osób starszych na wsi niż w mieście, przy czym wielkość miasta wpływała na odsetek takich opinii, gdyż badani z miast powyżej 100 tysięcy mieszkańców rzadziej deklarowali 
brak żywności lub obawy związane z jej brakiem niż mieszkańcy miast 100tysięcznych lub mniejszych.

Z Raportu Światowej Organizacji ds. Rolnictwa i Wyżywienia (FAO) wynika, że życie na obszarach wiejskich jest czynnikiem ryzyka zagrażającym bezpieczeństwu żywnościowemu. Stwierdzono, że szczególnie populacje stref obszarów wiejskich krajów rozwijających się stanowią wysoki odsetek ludzi cierpiących głód [7]. W badaniach meksykańskich wykazano większe rozpowszechnienie braku bezpieczeństwa żywnościowego w regionach wiejskich niż miejskich [12, 21], a odsetek gospodarstw domowych na obszarach wiejskich z brakiem gwarancji bezpieczeństwa żywnościowego w latach 2012 - 2016 wynosił średnio aż 78 \% [21].

Wykazano również, że wraz ze wzrostem wykształcenia odsetek badanych deklarujących brak żywności lub obawy związane z jej brakiem z powodu ograniczonych środków finansowych statystycznie istotnie zmniejszał się (tab. 2).

Ponadto na podstawie analizy MCA wykazano związek między wykształceniem średnim i wyższym a opinią, że w gospodarstwach domowych osób starszych z minimum średnim wykształceniem nie występuje brak żywności lub obawy związane z jej brakiem z powodu ograniczonych środków finansowych. Wzrost poziomu wykształcenia jest skorelowany $\mathrm{w}$ większym stopniu $\mathrm{z}$ dostępnością żywności, również pod względem ekonomicznym, na co wskazują wyniki badań amerykańskich [4, 11, 25], francuskich [1], portugalskich [5] oraz meksykańskich [12, 20].

Sytuacja braku bezpieczeństwa żywnościowego występuje przede wszystkim w gospodarstwach domowych z większą liczbą osób, w wieku powyżej 64 lat, na co wskazują Haro-Mota i wsp. [12]. W niniejszych badaniach wykazano, że statystycznie istotnie większy odsetek osób mieszkających samotnie lub mieszkających z rodziną deklarował brak żywności lub obawy związane z jej brakiem z powodu ograniczonych środków finansowych (tab. 2). Ponadto na podstawie analizy MCA wykazano związek między taką deklaracją a zamieszkaniem bez partnera i z rodziną. Porównywalne rezultaty opublikowali w 2018 roku Leroux i wsp. [16]. Wynika z nich, że brak bezpieczeństwa żywnościowego jest najbardziej rozpowszechniony wśród starszych mieszkających samotnie lub z osobami innymi niż ich partnerzy.

\section{Wnioski}

1. Ponad $25 \%$ badanej populacji osób starszych deklarowało brak żywności lub obawy związane z jej brakiem z powodu ograniczonych środków finansowych w ich gospodarstwach domowych.

2. Cechy socjodemograficzne, takie jak miejsce zamieszkania, wykształcenie i struktura gospodarstwa domowego były czynnikami statystycznie istotnie różnicującymi opinię o braku bezpieczeństwa żywnościowego w gospodarstwach domowych 
badanej grupy osób starszych, natomiast płeć i wiek to cechy, które nie wpływały na zróżnicowanie opinii.

3. Na podstawie analizy MCA wykazano związek między brakiem bezpieczeństwa żywnościowego w gospodarstwach domowych osób starszych a takimi cechami socjodemograficznymi, jak: wiek 75 lat i więcej, zamieszkanie na wsi, wykształcenie podstawowe, a pod względem składu osobowego gospodarstwa domowego zamieszkanie bez partnera, ale z rodziną.

4. Stosunkowo wysokie ryzyko braku bezpieczeństwa żywnościowego w gospodarstwach domowych osób starszych w badanych regionach Polski z powodu ograniczonych środków finansowych wymaga strategii wsparcia społecznego i państwowego w celu jego redukcji.

\section{Literatura}

[1] Bocquier A., Vieux F., Lioret S., Dubuisson C., Caillavet F., Darmon N.: Socio-ekonomic characteristics, living conditions and diet quality are associated with food insecurity in France. Public Health Nutrition, 2015, 18, 2952-2961.

[2] Dąbrowska A., Ozimek I.: Bezpieczeństwo żywnościowe konsumentów w Polsce - wybrane aspekty. Handel Wewnętrzny, 2014, 4 (351), 55-69.

[3] Darmon N., Caillavet F.: Food Insecurity: Determinants and impacts. In: Sustainable Nutrition in a Changing World. Eds. H.K. Biesalski, A. Drewnowski, J.T. Dwyjer, J.J. Strain, P. Weber, M. Eggersdorfer. Springer Int. Publ., Cham, Switzerland, 2017, pp. 125-141.

[4] Dean W.R., Sharkey J.R., Johnson C.M.: Food insecurity is associated with social capital, perceived personal disparity, and partnership status among older and senior adults in a largely rural area of central Texas. J. Nutr. Gerontol. Geriat., 2011, 30, 169-186.

[5] Donini L.M., Scardella P., Piombo L., Neri B., Asprino R., Proietti A.R., Morrone A.: Malnutrition in elderly: Social and economic determinants. J. Nutr., Health Aging, 2013, 17 (1), 9-15.

[6] Emery J.H., Fleisch V., McIntyre L.: How a guaranteed annual income could put food banks out of business. The School of Public Policy, 2013, 6 (37), 1-24.

[7] Fonseca-Centeno Z.Y., Álverez-Uribe M.C., Estrada-Restrepo A.: Caracterización de los hogeres colombianos en inseguridad alimentaria según calided de vida. Rev. Salud Pública, 2010, 12, 877888.

[8] Ganhão-Arranhado S., Paúl C., Ramalho R., Pereira P.: Food insecurity, weight and nutritional status among older adults attending senior centres in Lisbon. Archives of Gerontology and Geriatrics, 2018, 78, 81-88.

[9] Gawęcki J.: Pojęcie bezpieczeństwa żywności i żywienia. W: Bezpieczeństwo żywności i żywienia. Red. J. Gawęcki, Z. Krejpcio. Wyd. UP w Poznaniu, Poznań 2014.

[10] Gregório M.J., Rodrigues A.M., Graça P., de Sousa R.D., Dias S.S., Branco J.C., Ganhão H.: Food insecurity is associated with low adherence to the Mediterranean diet and adverse health contitions in Portuguese adults. Frontiers in Public Health, 2018, 6 (38), 1-9.

[11] Guo B.: Household assets and food security: Evidence from the Survey of Program Dynamics. J. Family Econ. Issues, 2011, 32, 98-110. 
[12] Haro-Mota R., Marceleño-Flores S., Bojórquez-Serrano J.I., Nájera-González O.: La inseguridad alimentaria en El estado de Nayarit, México, y su asociación con factores socioeconómicos. Salud Publica Mex., 2016, 58, 421-427.

[13] Informacja o sytuacji osób starszych w Polsce za rok 2017. [on line]. Ministerstwo Rodziny, Pracy i Polityki Społecznej. Dostęp w Internecie [29.07.2019]: https://www.gov.pl/attachment/27f34fef798d-47d5-8921-adb4a0b74595.

[14] Kamiński W.: Polityka i organizacja wyżywienia ludności. PWE, Warszawa 1980.

[15] Kraciuk J.: Bezpieczeństwo żywnościowe krajów Unii Europejskiej. Rocz. Nauk. Stow. Ekonom. Roln. Agrobiz., 2017, XIX (3), 150-155.

[16] Leroux J., Morrison K., Rosenberg M.: Prevalence and predictors of food insecurity among older pe ople in Canada. Int. J. Envir. Res. Public Health, 2018, 15, 2511-2518.

[17] Małysz J.: Bezpieczeństwo żywnościowe. Strategiczna potrzeba ludzkości. PWN, Warszawa 1991.

[18] Małysz J.: Bezpieczeństwo żywnościowe strategiczną potrzebą ludzkości. Almamer. Warszawa 2008.

[19] McIntyre L., Dutton D., Kwok C., Emery J.: Reduction of food insecurity in low-income Canadian seniors as a likely impast of a quaranteed annual income. Canadian Public Policy, 2016, 42, 274286.

[20] Mundo-Rosas V., Méndez-Gómez Humarán I., Shamah-Lexy T.: Caracterización de los hogares mexicanos en inseguridad alimentaria. Salud Publica Mex., 2014, 56 (supl. 1), 12-20.

[21] Mundo-Rosas V., Vizuet-Vega N.I., Martínez-Domínguez J., Morales-Ruán C., Pérez-Escamilla R., Shamah-Lexy T.: Evolución de la inseguridad alimentaria en los hogares mexicanos: 2012-2016. Salud Publica Mex., 2018, 60 (3), 309-318.

[22] Michalczyk J.: Bezpieczeństwo żywnościowe z perspektywy państw Unii Europejskiej. Ekonomia Międzynarodowa, 2019, 25, 18-44.

[23] Nord M., Coleman-Jensen A., Andrews M., Carleson S.: Household Food Security in the United States, 2009. US Department of Agriculture, Washington, DC, USA, 2010.

[24] Russell J., Flood V., Yeatman H., Mitchell P.: Prevalence and risk factors of food insecurity among a cohort of older Australians. J. Nutr. Health Aging, 2014, 18, 3-8.

[25] Sharkey J.R., Dean W.R., Nalty C.C.: Child hunger and the protective effects of Supplemental Nutrition Assistance Program (SNAP) and alternative food sources among Mexican-origin familie in Texsas border colonias. BMC Pedriatrics, 2013, 13, 143.

[26] Stanisz A.: Przystępny kurs statystyki. Tom 3. Analizy wielowymiarowe. Wyd. StatSoft, Kraków 2007.

[27] Tarasuk V., Fafard St-Germain A.A., Mitchell A.: Geographic and socio-demographic predictors of household food insecurity in Canada, 2011-2012. BMC Public Health, 2019, 19, 12-24.

\title{
ECONOMIC ASPECT OF FOOD SECURITY IN HOUSEHOLDS OF THE ELDERLY PEOPLE INCLUDING SELECTED SOCIO-DEMOGRAPHIC FEATURES
}

\author{
$\mathrm{S}$ u m m a r y
}

The major reasons of food insecurity in households of the elderly people are linked with poverty, social policy and incomes. The objective of the research study was to assess the food security in the households of the elderly people in terms of the economic aspect including some selected socio-demographic features. The research study was based on the author's own survey questionnaire. More than $25 \%$ of the surveyed expressed an opinion that the food shortage was present in their households or there were con- 
cerns resulting from their limited financial means. Gender and age were not the factors to statistically significantly differentiate that opinion (in line with the $\chi^{2}$ test), however the results of MCA (Multiple Correspondence Analysis) proved a correlation to exist between that opinion and the age of the respondents ( 75 and older). In turn, the place of residence, education and structure of people living together with the respondents in the same households were socio-demographic features that statistically significantly differentiated the above opinion of the respondents $\left(\chi^{2}\right)$. Moreover, based on the results of MCA, a correlation was proved to exist between the place of residence in a village, primary education, living without a partner, but with a family, and the opinion about the food insecurity. In order to ensure food security in the households of the elderly people, it is necessary to develop a state-provided and social assistance strategy.

Key words: food security, elderly people, survey research, socio-demographic features 